\title{
Clinical Reasoning: A Middle-aged Man With a History of Muscle Pain Presenting With Progressive Leukoencephalopathy and Subsequent Coma
}

Anna Sofie Jakobsson, MD, Ditte Gry Strange, MD, Kirsten Møller, MD, PhD, and Daniel Kondziella, MD, PhD Neurology ${ }^{\circledR}$ 2021;97:910-915. doi:10.1212/WNL.0000000000012486
Correspondence Dr. Kondziella daniel.kondziella@ regionh.dk

\section{Section 1}

A 44-year-old left-handed man was admitted in October 2016 for acute-onset tingling and weakness in the left arm, cheek, and tongue and speech difficulties. These symptoms completely disappeared 1 hour later but were followed by several hours of headache, nausea, and vomiting. The patient experienced self-limiting gastroenteritis 2 months earlier. His medical history was unremarkable except for mild muscle pain aggravated by physical activity starting 4 years earlier. He never experienced a migraine, and his family history was negative for neurologic disorders. Neurologic examination was normal. There was no joint swelling, rash, renal impairment, or ocular signs. The working diagnoses were transitory ischemic attacks and migraine with aura. Brain CT and ultrasonography of the carotid arteries were normal.

On day 2, the patient had another attack, again with remission of neurologic symptoms within 60 minutes but lasting headaches for several hours. Brain MRI showed a widespread subcortical white matter hyperintense signal on $\mathrm{T} 2$-weighted sequences in both hemispheres, with sparing of U-fibers, no thalamic or corpus callosal involvement, and no contrast enhancement (Figure, A and B). Blood analysis, including vasculitis panel and muscle enzymes, was normal except for an M-component with IgG 6.5 g/L, slightly increased levels of kappa $(19.7 \mathrm{mg} / \mathrm{L}$; normal 3.3-19.47 $\mathrm{mg} / \mathrm{L})$, increased kappa/lambda ratio, and hypercalcemia $(2.09 \mathrm{mmol} / \mathrm{L}$; normal $2.15-2.51$ $\mathrm{mmol} / \mathrm{L})$. CSF analysis revealed increased protein levels $(2.4 \mathrm{~g} / \mathrm{L}$; normal $0.15-0.5 \mathrm{~g} / \mathrm{L})$ and leukocytes (11E6/L; normal <5E6/L). IgG was $392.1 \mathrm{mg} / \mathrm{L}$ (normal $14-52 \mathrm{mg} / \mathrm{L}$ ), and the IgG index was elevated (0.67). CSF analysis was repeated after 11 and 19 days ( 9 mononuclear cells and $6.4 \mathrm{~g} / \mathrm{L}$ protein and 21 mononuclear cells and $3.03 \mathrm{~g} / \mathrm{L}$ protein, respectively). No oligoclonal bands were observed. Within 3 weeks of admission, the patient experienced 9 attacks akin to the first one, with complete remission of neurologic symptoms and subsequent headache. Although EEG did not reveal epileptic activity, the patient was started on levetiracetam $500 \mathrm{mg}$ twice daily.

\section{Questions for Consideration:}

1. What is your differential diagnosis?

2. What diagnostic testing would you consider?

From the Department of Neurology (A.S.J., D.K.), Rigshospitalet, Copenhagen University Hospital, Copenhagen; Department of Anesthesiology (D.G.S.), Bispebjerg, Copenhagen University Hospital, Copenhagen; Department of Neuroanesthesiology (K.M.), Rigshospitalet, Copenhagen University Hospital, Copenhagen; and Department of Clinical Medicine (K.M., D.K.), University of Copenhagen, Denmark.

Go to Neurology.org/N for full disclosures. Funding information and disclosures deemed relevant by the authors, if any, are provided at the end of the article.

Ethics statement: The patient has provided written consent for publication. 
Figure Brain MRI

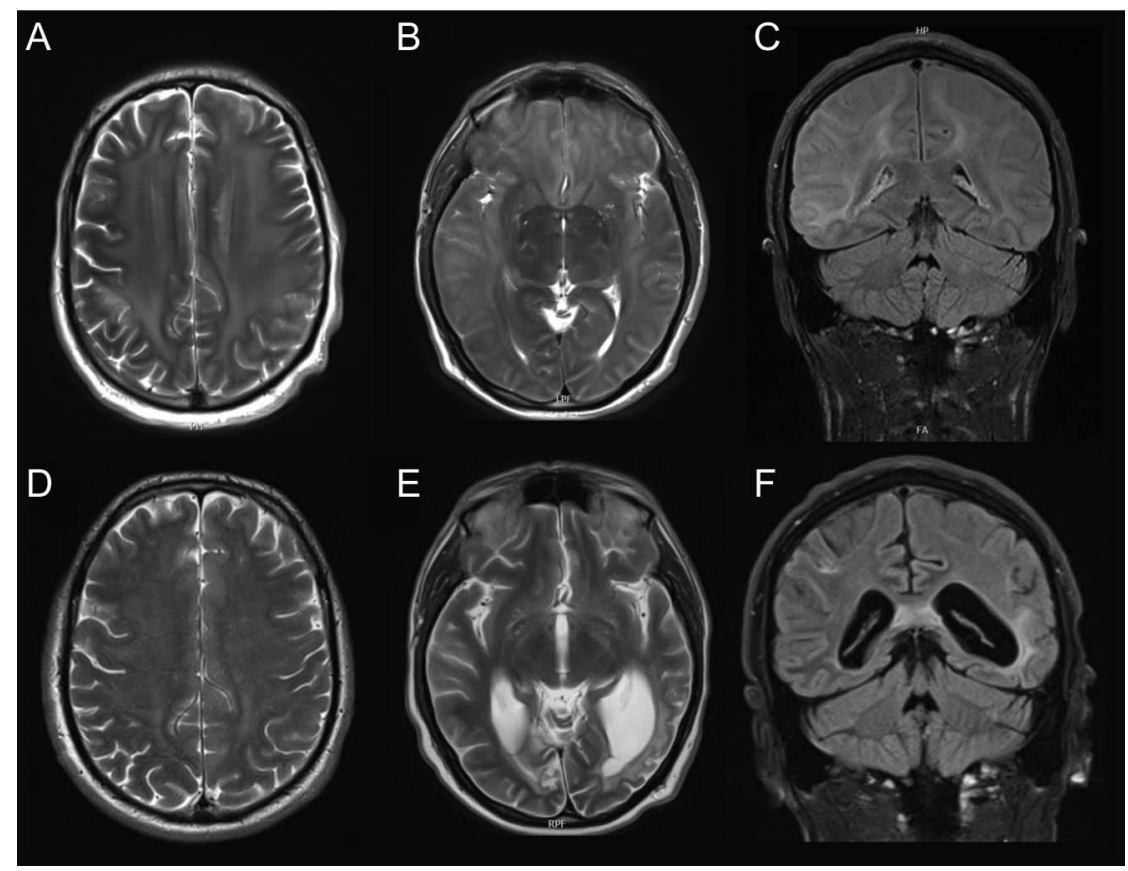

Brain MRI (A and B, axial T2-weighted; C, coronal FLAIR) from early in the disease course shows a Ufiber sparing leukoencephalopathy, consistent with generalized brain edema, and no gadolinium contrast enhancement (T1-weighted with gadolinium not shown). At the follow-up of 3 years later ( $D$ and $E$, axial T2-weighted; F, coronal FLAIR), brain edema has remitted, but there is brain atrophy, including ventricular enlargement, most pronounced at the occipital lobe on the left side, consistent with a secondary neurodegenerative process. FLAIR = fluidattenuated inversion recovery.

\section{GO TO SECTION 2}




\section{Section 2}

Given the history of repeated TIA-like attacks with lateralized sensorimotor symptoms and aphasia associated with bifrontal headache, nausea and vomiting, leukoencephalopathy on brain imaging, and inflammatory CSF analysis, the differential diagnoses included infectious or autoimmune-mediated inflammatory disorders, lymphoma, and cerebral autosomal dominant arteriopathy with subcortical infarcts and leukoencephalopathy (CADASIL). The differential diagnosis of headache with stroke-like episodes also includes mitochondrial encephalopathy with lactic acidosis and stroke-like episodes (MELAS) and transient headache and neurologic deficits with CSF lymphocytosis (HaNDL), but neither MELAS nor HaNDL was concordant with the MRI findings. The relevance of the 4-year history of muscle pain associated with physical activity was uncertain at this stage.

The primary working diagnosis was lymphoma owing to the positive M-component, increased kappa/lambda ratio, and inflammatory CSF. Lymphoma can present with fluctuating neurologic symptoms, although the lack of contrast enhancement on brain MRI is unusual. Because the patient had had gastroenteritis 2 months before disease onset, acute demyelinating encephalomyelitis or another postinfectious disorder was considered. Autoimmune encephalitis was also considered; however, there were no psychiatric features. The absence of gadolinium enhancement on MRI pointed against sarcoidosis and antimyelin oligodendrocyte glycoprotein (MOG) disease. Infectious encephalitis, such as HIV, might have been conceivable, but the relapsingremitting symptoms did not fit. Finally, CADASIL was possible owing to migraine-like episodes and leukoencephalopathy, although inflammatory CSF changes would be very unusual, and there were no T2-weighted hyperintensities involving the bilateral anterior temporal lobes or the external capsules.

CSF and blood examinations showed negative results for herpes simplex virus, HIV, Epstein-Barr virus, cytomegalovirus, varicella zoster virus, tick-borne encephalitis, mycoplasma, syphilis, Borrelia sp., and $16 \mathrm{~S}$ ribosomal RNA sequencing. Furthermore, synaptic antineuronal, paraneoplastic, IL-2 receptor, aquaporin 4, anti-MOG, and thyroid antibodies (CSF and plasma); angiotensin-converting enzyme; and CSF cytology and flow cytometry were all negative. Notch Receptor 3 (NOTCH3) and lysosomal diseases showed negative results on genetic testing. Flow cytometry and bone marrow biopsy results were normal. Whole-body PET-CT showed no signs of malignancy or sarcoidosis.

Twenty-eight days after symptom onset, the patient did not have any focal neurologic deficits but was confused. The CSF examination was repeated, and shortly thereafter, the patient developed severe headache and vomiting without the usual left-sided neurologic deficits. The patient's vital signs were normal. He was calm but dysphasic and unable to recognize faces; he answered questions only after several seconds, and he had ideomotor and ideational apraxia and impaired working memory. CSF examinations revealed increased protein $3.42 \mathrm{~g} / \mathrm{L}, 10$ cells E6/L, and IgG $420 \mathrm{mg} / \mathrm{L}$. Brain CT angiography showed generalized cerebral edema but preserved white-gray demarcation, open basal cisterns, no ventricular enlargement, and normally appearing vessels. Another MRI revealed unchanged leukoencephalopathy with symmetrical confluent white matter hyperintensity, U-fiber sparing, and no contrast enhancement. Diffusion-weighted sequences did not show any ischemic changes. Brain PET showed decreased metabolic activity, mainly bifrontotemporal, matching the white matter lesions on MRI. EEG showed an encephalopathic pattern. A hematologic consultant diagnosed the patient with monoclonal gammopathy of undetermined significance (MGUS) based on the positive M-component with IgG kappa and increased kappa/lambda ratio.

At this point, it was felt that lymphoma, sarcoidosis, metabolic diseases, infectious agents, and postinfectious disorders were unlikely. The patient was treated with IV methylprednisolone ( $1 \mathrm{~g}$ daily for 5 days), followed by oral prednisone $(100 \mathrm{mg}$ ), which was decreased over 14 days to $25 \mathrm{mg}$ daily. The patient fully recovered and was discharged. Repeated lumbar puncture and neuroimaging 1 month later showed normal CSF and near-normal MRI. Although white matter changes were still present, they were less pronounced. The patient was diagnosed with steroid-responsive inflammatory leukoencephalopathy of uncertain etiology.

\section{Questions for Consideration:}

1. How would you manage this patient now?

2. What are the implications of the last MRI showing diminished, albeit persisting leukoencephalopathy? 


\section{Section 3}

The patient was managed for 2 years with low-dose prednisone, a steroid-sparing agent (azathioprine), and an antiepileptic drug (levetiracetam). Although the patient could return to work full-time, he had minor relapses every time the prednisone was phased out, consistent with suppressed but ongoing disease activity, as revealed by MRI. In February 2019, the patient was readmitted with a 3-week history of diarrhea, vomiting, and altered mental state. His Montreal Cognitive Assessment score was 16/30. He was started on high-dose IV methylprednisolone, and a new CSF examination showed no cells, protein $3.88 \mathrm{~g} / \mathrm{L}$, IgG $476 \mathrm{mg} / \mathrm{L}$, and increased neurofilament light protein $(1,136 \mathrm{ng} / \mathrm{L})$. Five days later, he became comatose and was intubated. Brain CT showed supratentorial and infratentorial cerebral edema with obliterated basal cisterns and herniation. He was transferred to the intensive care unit
(ICU) for the management of elevated intracranial pressure (ICP). EEG monitoring revealed no epileptic activity. Blood workup showed normal creatine phosphokinase but elevated plasma myoglobin $(1,120 \mu \mathrm{g} / \mathrm{L}$; normal 24-77 $\mu \mathrm{g} / \mathrm{L})$. Over the next 3 days, he developed multiorgan failure and massive generalized body edema, including excessive body fluid ( 21 L). Blood pressure was kept stable using noradrenaline. Hemoconcentration was noted, topping at $13.3 \mathrm{mmol} / \mathrm{L}$ (normal 8.3-10.5 g/L). Blood tests revealed hypoalbuminemia and a 10-fold increase in IgG4 levels. Despite aggressive management, including barbiturate coma, ICP was rising. A final diagnosis was made on the third day of admission to the ICU.

\section{Questions for Consideration:}

1. What is the diagnosis?

2. Which treatment(s) should be considered? 


\section{Section 4}

Based on the clinical symptoms, including a history of muscle pain with physical activity and massive peripheral capillary leakage with excessive body fluid, hemoconcentration, brain edema, and MGUS with a 10-fold increase in IgG4, the patient was diagnosed with monoclonal gammopathy-associated systemic capillary leak syndrome, also known as Clarkson disease. The patient was started on intravenous immunoglobulin (IVIG), and intravenous epoprostenol was administered. Eculizumab to inhibit C5 complement was considered but not given because ICP decreased over the ensuing days. After 1.5 months of ICU treatment, the patient was awake but tetraplegic. Nerve conduction studies were consistent with critical illness polyneuromyopathy. He was referred for rehabilitation. Six months after ICU discharge, the patient had no headaches, but the examination showed amnestic dysfunction, a rightsided homonym visual field defect, and poor facial recognition. One year later, he worked part-time, but he was unable to regain his previous job position. He was treated with subcutaneous immunoglobulin ( $2 \mathrm{~g}$ per month), prednisone ( 25 $\mathrm{mg}$ ), and azathioprine (200 mg daily). Brain MRI was notable for secondary cerebral atrophy, including enlargement of the posterior horn and occipital atrophy on the left (Figure, $\mathrm{C}$ and D), consistent with his right-sided visual field defect.

\section{Discussion}

Clarkson disease is a rare syndrome, with 250 reported cases since $1960 .^{1-6}$ The average onset is in the mid-40s. ${ }^{7,8}$ Little is known about the triggering factors and the pathophysiology, which involves recurrent episodes of vascular leakage of fluids and proteins into peripheral tissues, resulting in whole-body edema and hypotensive shock. ${ }^{3}$ Genetic factors, ${ }^{9}$ neutrophil activation, ${ }^{6}$ and adrenomedullin surges ${ }^{4}$ have been implicated. The severity and frequency of attacks vary from once in a lifetime to several attacks per year. ${ }^{7,8}$ Antecedent flu-like illness is seen in $30 \%$ of patients. Sustained physical exertion can also trigger attacks. ${ }^{7}$ Prodromal symptoms precede more serious signs by 1-2 days in approximately half of all patients, including fatigue, edema, polydipsia, abdominal pain, decreased urinary output, nausea, myalgia, and an increase in body weight. Subsequent neurologic complications include coma, status epilepticus, and cerebral edema leading to brain herniation..$^{10,11}$ The survival rate was traditionally very low but has improved with increasing recognition and use of preventive therapies. ${ }^{3}$ Specifically, therapy with immunoglobulins is the strongest factor associated with survival. ${ }^{3}$ Our patient had several less severe attacks managed with prednisone before the diagnosis was made. The disease was finally recognized owing to the history of muscle pain and edema after exercise, MGUS, very high IgG4 levels, progressive leukoencephalopathy, and massive body edema, indicative of systemic leakage. Although it cannot be ruled out that the history of exercise-induced muscle pain is coincidental, we believe this is unlikely. Indeed, in a case series of 34 patients with Clarkson disease, a history of muscle pain was noted in 14 patients $(56 \%) .^{8}$ Similarly, although transient neurologic symptoms have not been described in detail before in Clarkson syndrome, we believe these symptoms were manifestations of capillary leakage rather than another unrelated disorder. After IVIG treatment, remarkable remission was observed; at the time of this writing, the patient had no focal neurologic deficits except for a visual field defect and moderate-to-severe cognitive deficits compatible with prolonged inflammatory brain edema and secondary cerebral atrophy. In summary, Clarkson disease can present with leukoencephalopathy with fluctuating, progressive neurologic deficits, culminating in a coma due to increased ICP. Despite an overall good outcome, there can be substantial secondary brain atrophy on follow-up.

\section{Study Funding}

The authors report no targeted funding.

\section{Disclosure}

D. Kondziella is an Associate Editor with Acta Neurologica Scandinavica and has received financial compensation for this activity from the publisher Wiley. The other authors report no disclosures relevant to the manuscript. Go to Neurology.org/ $\mathrm{N}$ for full disclosures.

\section{Appendix Authors}

\begin{tabular}{|c|c|c|}
\hline Name & Location & Contribution \\
\hline $\begin{array}{l}\text { Anna Sofie } \\
\text { Jakobsson, } \\
\text { MD }\end{array}$ & $\begin{array}{l}\text { Department of Neurology, } \\
\text { Rigshospitalet, Copenhagen } \\
\text { University Hospital, } \\
\text { Copenhagen, Denmark }\end{array}$ & $\begin{array}{l}\text { Drafting/revision of the } \\
\text { article for content, including } \\
\text { medical writing for content, } \\
\text { and analysis or interpretation } \\
\text { of data }\end{array}$ \\
\hline $\begin{array}{l}\text { Ditte Gry } \\
\text { Strange, } \\
\text { MD }\end{array}$ & $\begin{array}{l}\text { Department of } \\
\text { Anesthesiology, Bispebjerg } \\
\text { Hospital, Copenhagen } \\
\text { University Hospital, } \\
\text { Copenhagen, Denmark }\end{array}$ & $\begin{array}{l}\text { Drafting/revision of the } \\
\text { article for content, including } \\
\text { medical writing for content; } \\
\text { major role in the acquisition } \\
\text { of data; and analysis or } \\
\text { interpretation of data }\end{array}$ \\
\hline $\begin{array}{l}\text { Kirsten } \\
\text { Møller, MD, } \\
\text { PhD }\end{array}$ & $\begin{array}{l}\text { Department of } \\
\text { Neuroanesthesiology, } \\
\text { Rigshospitalet, Copenhagen } \\
\text { University Hospital, and } \\
\text { Department of Clinical } \\
\text { Medicine, University of } \\
\text { Copenhagen, Denmark }\end{array}$ & $\begin{array}{l}\text { Drafting/revision of the } \\
\text { article for content, including } \\
\text { medical writing for content; } \\
\text { major role in the acquisition } \\
\text { of data; and analysis or } \\
\text { interpretation of data }\end{array}$ \\
\hline $\begin{array}{l}\text { Daniel } \\
\text { Kondziella, } \\
\text { MD, PhD }\end{array}$ & $\begin{array}{l}\text { Department of Clinical } \\
\text { Medicine, University of } \\
\text { Copenhagen, and } \\
\text { Department of Clinical } \\
\text { Medicine, University of } \\
\text { Copenhagen, Denmark }\end{array}$ & $\begin{array}{l}\text { Drafting/revision of the } \\
\text { article for content, including } \\
\text { medical writing for content; } \\
\text { major role in the acquisition } \\
\text { of data; study concept or } \\
\text { design; and analysis or } \\
\text { interpretation of data }\end{array}$ \\
\hline
\end{tabular}

\section{References}

1. Dhir V, Arya V, Malav IC, Suryanarayanan BS, Gupta R, Dey AB. Idiopathic systemic capillary leak syndrome (SCLS): case report and systematic review of cases reported in the last 16 years. Intern Med. 2007;46(12):899-904.

2. Sion-Sarid R, Lerman-Sagie T, Blumkin L, Ben-Ami D, Cohen I, Houri S. Neurologic involvement in a child with systemic capillary leak syndrome. Pediatrics. 2010;125(3): e687-e692. 
3. Siddall E, Khatri M, Radhakrishnan J. Capillary leak syndrome: etiologies, pathophysiology, and management. Kidney Int. 2017;92(1):37-46.

4. Xie Z, Chen WS, Yin Y, et al. Adrenomedullin surges are linked to acute episodes of the systemic capillary leak syndrome (Clarkson disease). J Leukoc Biol. 2018;103(4): 749-759.

5. Druey KM, Parikh SM. Idiopathic systemic capillary leak syndrome (Clarkson disease). J Allergy Clin Immunol. 2017;140(3):663-670.

6. Xie Z, Kuhns DB, Gu X, et al. Neutrophil activation in systemic capillary leak syndrome (Clarkson disease). J Cell Mol Med. 2019;23(8):5119-5127.

7. Gousseff M, Arnaud L, Lambert M, et al. The systemic capillary leak syndrome: a case series of 28 patients from a European registry. Ann Intern Med. 2011;154(7):464-471.
8. Kapoor P, Greipp PT, Schaefer EW, et al. Idiopathic systemic capillary leak syndrome (Clarkson's disease): the Mayo clinic experience. Mayo Clin Proc. 2010;85(10): 905-912.

9. Raza A, Xie Z, Chan EC, et al. A natural mouse model reveals genetic determinants of systemic capillary leak syndrome (Clarkson disease). Commun Biol Nat Res. 2019; 2(1):398.

10. Ohira J, Yoshimura H, Takanashi M, et al. Extensive leukoencephalopathy associated with idiopathic capillary leak syndrome: report of a case with neuropathology. Neurol Sci. 2021;42(5):2095-2098.

11. Bertorini TE, Gelfand MS, O’Brien TF. Encephalopathy due to capillary leak syndrome. South Med J. 1997;90(10):1060-1062.

\section{Manage Your Career | Recruit Top Talent}

The AAN's Neurology Career Center is the largest job site specifically for neurologists. Visit careers.aan.com to find your next hire or search from hundreds of open positions in neurology.

\section{Neurology $y^{\circledast}$ Online CME Program}

Earn CME while reading Neurology. This program is available only to online Neurology subscribers. Read the articles marked CME, go to Neurology.org, and click on CME. This will provide all of the information necessary to get started. The American Academy of Neurology (AAN) is accredited by the Accreditation Council for Continuing Medical Education (ACCME) to sponsor continuing medical education for physicians. Neurology is planned and produced in accordance with the ACCME Essentials. For more information, contact AAN Member Services at 800-879-1960.

\section{Sign Up for the AAN's Axon Registry}

The AAN encourages its US members to show their interest in participating in the Axon Registry ${ }^{\circledR}$ by signing up today.

Use the Axon Registry to:

- Simplify reporting requirements under MACRA's Quality Payment Program and avoid penalties while reducing your administrative burden

- Meet your MOC Part IV requirements and waive up to eight credits of Part II Self-Assessment

- Choose from 22 AAN neurology-specific quality measures that fit your practice

- Use data to understand your practice and identify where improvements can be made to patient care

- Manage your patients at a population level; look at a specific group of patients based on conditions, risk factors, demographics or outcome

- Demonstrate your value to payers when negotiating reimbursement

- Enjoy multi-year, fee-free access when you sign the agreements and integrate your EHR with the registry

Learn more at AAN.com/view/Axon and send your questions to registry@aan.com. 


\section{Neurology}

\section{Clinical Reasoning: A Middle-aged Man With a History of Muscle Pain Presenting With Progressive Leukoencephalopathy and Subsequent Coma}

Anna Sofie Jakobsson, Ditte Gry Strange, Kirsten Møller, et al. Neurology 2021;97;910-915 Published Online before print July 14, 2021

DOI 10.1212/WNL.0000000000012486

\section{This information is current as of July 14, 2021}

\section{Updated Information \& Services}

References

Subspecialty Collections

Permissions \& Licensing

Reprints including high resolution figures, can be found at: http://n.neurology.org/content/97/19/910.full

This article cites 11 articles, 0 of which you can access for free at: http://n.neurology.org/content/97/19/910.full\#ref-list-1

This article, along with others on similar topics, appears in the following collection(s):

All Headache

http://n.neurology.org/cgi/collection/all_headache

Autoimmune diseases

http://n.neurology.org/cgi/collection/autoimmune_diseases

Coma

http://n.neurology.org/cgi/collection/coma

Critical care

http://n.neurology.org/cgi/collection/critical_care

Information about reproducing this article in parts (figures,tables) or in its entirety can be found online at:

http://www.neurology.org/about/about_the_journal\#permissions

Information about ordering reprints can be found online:

http://n.neurology.org/subscribers/advertise

Neurology ${ }^{\circledR}$ is the official journal of the American Academy of Neurology. Published continuously since 1951, it is now a weekly with 48 issues per year. Copyright @ 2021 American Academy of Neurology. All rights reserved. Print ISSN: 0028-3878. Online ISSN: 1526-632X.

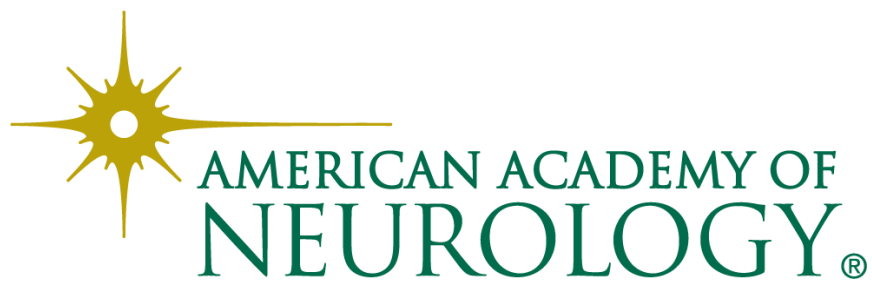

